\title{
Sistem Keamanan Model Sidik Jari (Digital Key Security) Menggunakan Pemrograman Arduino Pada Sepeda Motor
}

\author{
Danang Yugo Pratomo \\ Teknik Otomotif, Politeknik Hasnur, Indonesia \\ e-mail: d.yugo.pr@gmail.com
}

\begin{abstract}
Abstrak: Sistem keamanan berkendara model digital keys jenis sidik jari menawarkan sistem keamanan yang akurat dalam meminimalisir unit sepeda motor dari potensi tindak pidana pencurian yang marak terjadi. Penelitian ini bertujuan untuk mengembangkan sistem keamanan model sidik jari pada sepeda motor dengan metode pengembangan prototype berbasis Arduino. Pengujian dilakukan untuk mengetahui hasil konfigurasi pemrograman arduino pada board dengan scanner finger print. Hasil penelitian:1) konfigurasi yang diolah menggunakan aplikasi arduino menunjukkan done compiling yang memiliki makna konfigurasi berhasil. 2) Hasil pengujian scanning sidik jari menunjukkan bahwa penyalaan starter lebih cepat ketika telapak jari kondisi kering, yaitu rata-rata teraktifasi 2,31 detik. 3) Hasil deteksi terhadap sidik jari tak dikenal akan mengaktifkan alaram.
\end{abstract}

\section{Kata kunci: Sistem keamanan, Sidik jari, Aplikasi arduino}

\begin{abstract}
The fingerprint-type digital key model driving safety system offers an accurate security system in minimizing motorcycle units from potential theft crimes that are rampant. This study aims to develop a security system for a fingerprint model on a motorcycle using the arduino-based prototype development method. The test was carried out to determine the results of the arduino programming configuration on the board with a fingerprint scanner. Research results: 1) the design processed using the Arduino application shows that done compiling means that the configuration is successful. 2) The fingerprint scanning test results show that the ignition of the starter is faster when the palm of the finger is dry; that is, the average is activated 2.31 seconds. 3 ) The result of detection on unknown finger will be activate the alarm.
\end{abstract}

\section{Keywords: Security system, Fingerprint, Arduino application}

Seiring perkembangan jaman, semakin maju pula peradaban, teknologi, dan ilmu pengetahuan. Berbagai kemudahan ditawarkan market melalui fitur-fitur yang canggih dan berbasis serba teknologi. Hal ini pula yang menjadi tren perkembangan otomotif di masa kini dengan hadirnya fitur-fitur tambahan berbasis teknologi digital baik tambahan versi pabrikan maupun versi akesori modifikasi yang tersedia di market store (Kementerian Perindustrian Republik Indonesia, 2018). Teknologi digital berupa sistem sekuriti contohnya keyless berbasis bluethooth, push button keyless, biometrik fingerprint, bahkan sistem starter berbasis ponsel pintar. Biometric fingerprint security system telah jamak digunakan (Brijet et al., 2017). Setiap orang memiliki keunikan pada jari-jarinya yaitu sidik jari yang berbeda satu sama lainnya diseluruh dunia. Teknologi ini sangat tepat digunakan sebagai sistem pengaman yang sifatnya privasi seperti pada ponsel pintar, kunci brankas, alat presensi digital, hingga sistem strarter pada kendaraan pribadi (Khan et al., 2017).

Sistem strarter dengan perlindungan tambahan menggunakan fingerprint dapat diinput menggunakan aplikasi arduino. Aplikasi arduino merupakan aplikasi open source berupa mikro single-board yang didalamnya terdapat chip mikrokontroler AVR (Hendrawan \& Pratomo, 2020). Konfigurasi yang diprogram oleh programmer inilah yang dapat dimanfaatkan untuk penambahan sistem sekuriti pada kendaraan bermotor. Penyetelan awal atau starter yang biasanya konvensional menggunakan kunci kontak dimodifikasi sehingga penyalaan dialihkan menggunakan sidik jari, sehingga hanya pengguna yang terdaftar saja yang dapat mengakses kendaraan tersebut. Dengan demikian cara ini dapat menanggulangi atau meminimalisir pencurian menggunkan kunci letter $\mathrm{T}$ yang marak terjadi karena siapapun yang berusaha mencuri kendaraan akan dibuat kesulitan dalam menyalakan mesin (Prasetya \& Mushlihudin, 2018). 
Ada beberapa penelitian yang telah dilakukan dalam modifikasi sistem starter dengan penambahan sistem sekuriti untuk meningkatkan keamanan kendaraan dari potensi kemalingan. Sistem keamanan sepeda motor berbasis telephone menawarkan desain berupa autocall to user ketika sepeda motor dinyalakan oleh seseorang yang sidikjarinya belum terdaftar dalam database (Bachri, 2018). Hasil penelitian lainnya berupa sistem keamanan menggunakan kata sandi dengan batas percobaan tiga kali akses untuk menyalakan mesin, apabila melebihi daripada itu maka alaram pada sepeda motor tersebut akan berbunyi. Dalam desain tersebut menggunakan arduino uno dan remote infra merah yang dikonfigurasikan (Prasetya \& Mushlihudin, 2018).

Dalam perancangan desain ini mencoba untuk membuat sebuah prototype sekuriti pada kendaraan sepeda motor roda dua tipe matic menggunakan pemgrograman mikrokontroler arduino, board arduino uno, dan scanner biometric fingerprint. Ketiga kompenen tersebut dikonfigurasikan menjadi satu supaya menghasilkan produk yang dimaksud.

\section{METODE}

Penelitian ini menggunakan desain perancangan produk dengan luaran berupa prototype strarter sidik jari yang memiliki tingkat keamanan yang unik sehingga desain prototype tersebut susah untuk dijebol tingkat keamanannya. Secara umum langkah-langkah yang dilakukan dapat dibagi menjadi dua langkah, yaitu proses desain pemrograman dan proses uji kelayakan. Skema tahapan penelitian dijelaskan pada gambar diagram berikut.

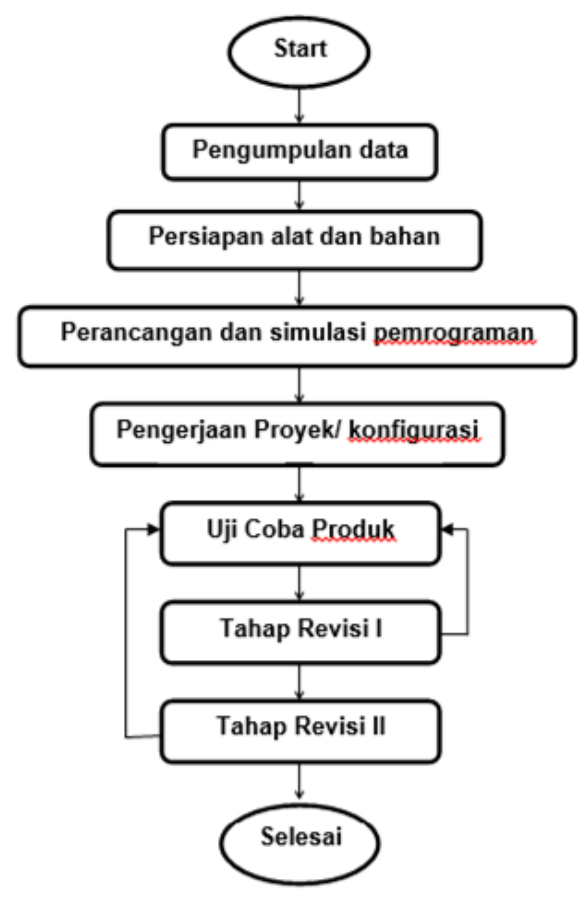

Gambar 1. Diagram alir penelitian

Penelitian ini dimulai dengan menyusun data-data terkait yang mendukung pengembangan meliputi review literatur terkait, alat dan bahan yang tentunya akan sangat mempengaruhi hasil pengembangan produk. Detil informasi perancangan dijelaskan pada paragraf di bawah ini.

\section{Persiapan alat dan bahan}

Adapun peralatan dan bahan yang digunakan dalam pembuatan rancangan ini antaralain: solder, timah, tang pengupas kabel, multitester, obeng plus dan minus, cutter, kabel, laptop, aplikasi arduino uno, board arduino, scanner biometric fingerprint, modul relay 2 channel. 


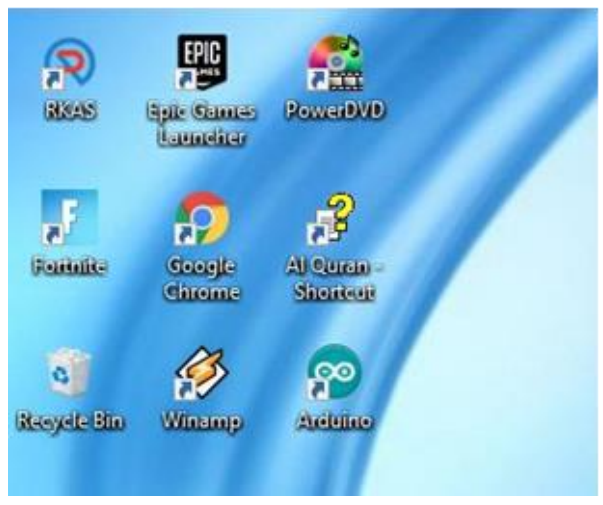

Gambar 2. Aplikasi arduino

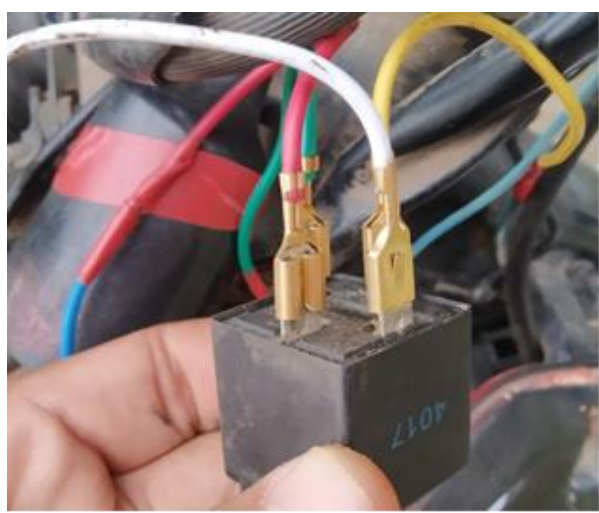

Gambar 3. Relay empat kaki

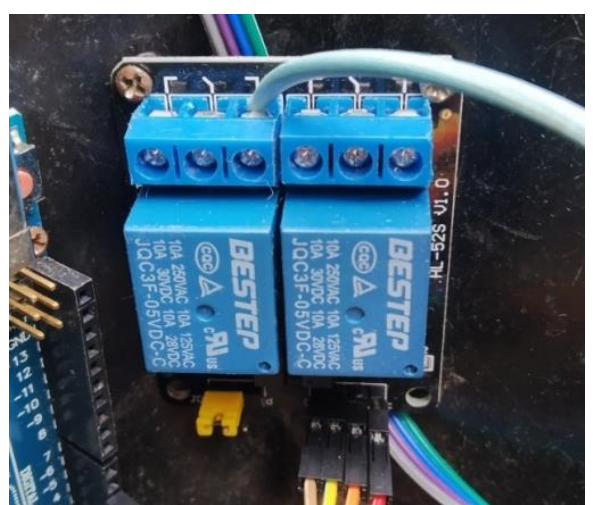

Gambar 4. Modul relay 2 channel

\section{Perancangan dan simulasi program aruino}

Perancangan pertama dimulai dengan merangkai bahan-bahan di atas dalam sebuah sistem kelistrikan untuk starter sidik jari yang nantinya akan dilanjutkan pada pemrograman melalui aplikasi arduino. Berikut ini wiring diagram kelistrikan starter sidik jari. 


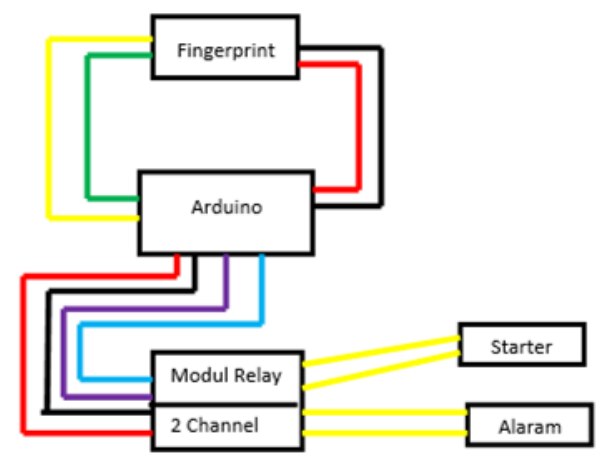

Gambar 5. Wiring diagram modul starter sidik jari

Dari wiring diagram modul starter sidik jari tersebut dapat diketahui bahwa kabel warna merah adalah VCC, kabel warna hitam adalah ground, kabel warna kuning dan hijau adalah RX TX dari scanner biometric sidik jari ke arduino. Kabel warna ungu adalah in-1 dan warna biru adalah in-2. Fungsi in-1 untuk menyalakan relay-1, sedangkan fungsi in-2 untuk menyalakan relay-2. Kabel kuning untuk menuju ke bagian outputnya, yaitu relay-1 ke starter, dan relay-2 ke alarm.

Tahap selanjutnya adalah setup modul starter fingerprint, dengan cara menghubungkan modul scanner fingerprint pada board arduino dan meneruskan pada laptop menggunakan kabel USB 2.0 Type A/B. Dalam setup ini terdapat pin yang harus dipasang, yaitu pin board arduino dengan pin scanner fingerprint.

Tabel 1. Setup pin board arduino dengan modul fingerprint scanner

\begin{tabular}{cc}
\hline Board Arduino Uno & Modul Fingerprint Scanner \\
\hline $5 \mathrm{~V}$ & VCC \\
GND & GND \\
Pin 10 & RXD \\
Pin 11 & TXD \\
\hline
\end{tabular}
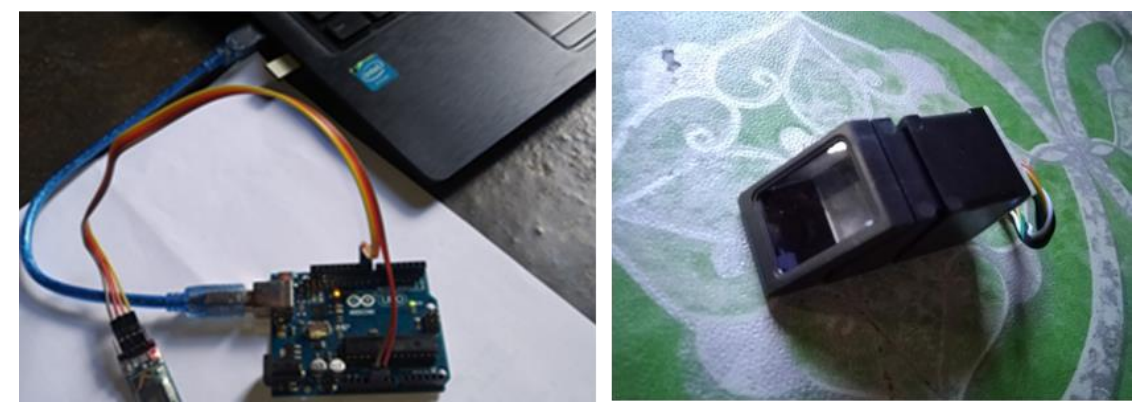

Gambar 6. Setup modul board arduino uno dengan scanner sidik jari menggunakan aplikasi arduino

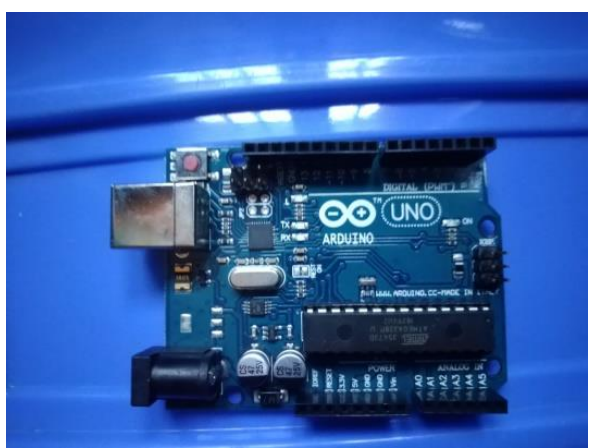

Gambar 7. Board arduino uno 
Jika pin sudah terpasang, selanjutnya adalah menuangkannya dalam bahasa pemrograman yaitu aplikasi arduino yang sudah terinstal pada laptop. Adapun bahasa coding yang diunggah kedalam board arduino untuk setup pada modul sidik jari pada Gambar.8 untuk lebih detilnya. Setelah semua coding sudah tertulis pada aplikasi arduino, selanjutnya tekan perintah verify untuk memverifikasi kode program sekaligus sebagai tindakan koreksi jika terdapat kesalahan. Progress selanjutnya adalah pemberitahuan status keberhasilan yang ditandai dengan keterangan Done Compiling. Selanjutnya masuk ke menu tools pada aplikasi dan pilih jenis board arduino uno dan tentukan jenis port yang akan digunakan, kemudian tekan perintah upload untuk mengunggah ke board arduino uno hingga aplikasi menunjukkan keterangan Done Compiling yang artinya program telah selesai diunggah.

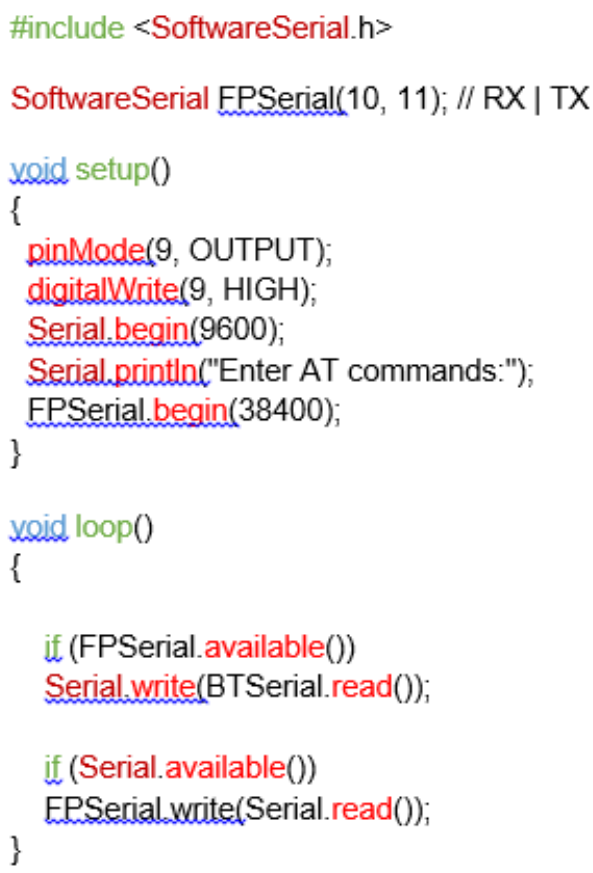

Gambar 8. Input coding pins pada aplikasi arduino

Setelah coding pin selesai diunggah dan berhasil, langkah selanjutnya adalah proses sketching program arduino yang akan diunggah ke dalam board arduino uno yang terintegrasi dengan scanner fingerprint modul. Proses ini merupakan sebuah proses yang mensimulasikan aplikasi produk/ prototype sekuriti yang dirancang akan bekerja atau tidak. Berikut ini adalah sketch program yang akan diunggah dalam board arduino uno sebagai sistem sakelar strarter motor dengan sekuriti fingerprint pada sepeda motor: 


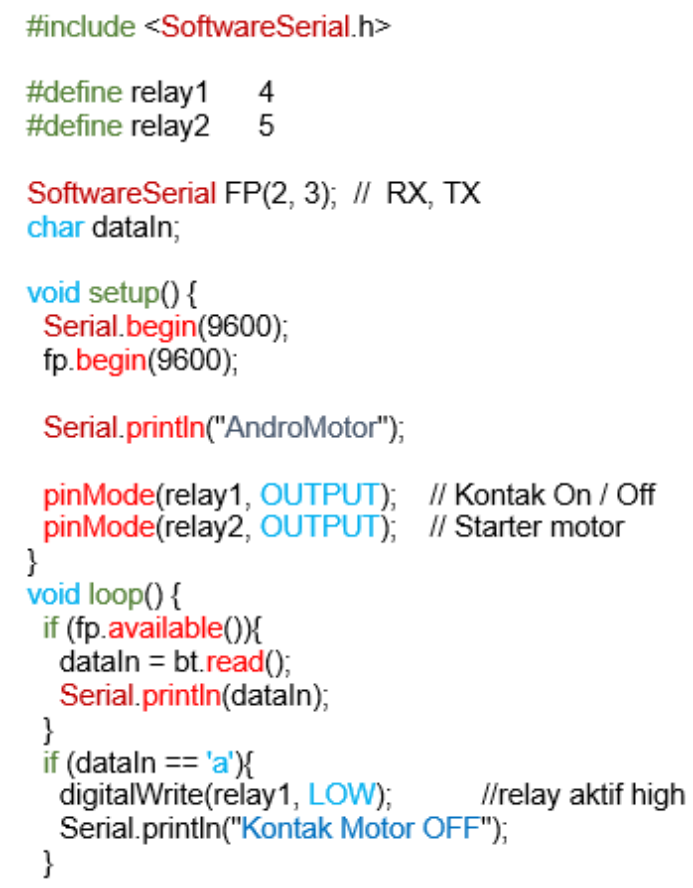

Gambar 9. Input coding sketch pada sistem sakelar strarter motor dengan sekuriti fingerprint pada sepeda motor menggunakan aplikasi arduino

Sebagaimana langkah pengunggahan bahasa coding pins, maka coding sketch ini dilanjutkan dengan verifikasi hingga menunjukkan keterangan Done Compiling jika tidak terdapat kesalahan pemrograman. Setelah itu lakukan pengunggahan dengan memastikan terlebih dahulu board arduino, port, kabel USB 2.0 type A/B terhubung satusamalain dengan mengisikan konfigurasi pada aplikasi arduino pada menu tools. Langkah terakhir adalah mengunggah program tersebut ke board arduino dan tunggu aplikasi arduino memberikan keterangan Done Compiling, maka program sudah terunggah dalam board arduino uno.

\section{Langkah pengerjaan proyek/ konfigurasi}

Langkah pengerjaan proyek selanjutnya adalah pemasangan sistem sakelar starter pada sepeda motor. Awal yang harus dilakukan adalah melepas box sepeda motor seperti batok kepala motor, sayap, bagasi dan bodi yang bertujuan untuk memudahkan pemasangan konfigurasi sistem sakelar fingerprint arduino board dengan sistem kelistrikan sepeda motor itu sendiri. Kemudian merangkai board arduino uno dengan aki yang dijembatani oleh DC converter regulator yang berfungsi menurunkan tegangan aki dari 12 volt DC menuju ke board arduino uno yang memiliki tegangan stabil 5 volt DC sehingga nantinya board arduino dapat bekerja dengan tegangan yang aman sesuai spesifikasinya. Setelah itu dilanjutkan dengan merangkai sedemikian rupa pada bagasi sepeda motor, yaitu rangkaian modul relay 2 channel dan modul scanner fingerprint. Khusus scanner finger print ditempatkan diluar bagasi yang aman dari potensi terkena air. Konfigurasi ini harus memperhatikan pemasangan kabel sesuai dengan wiring diagram.

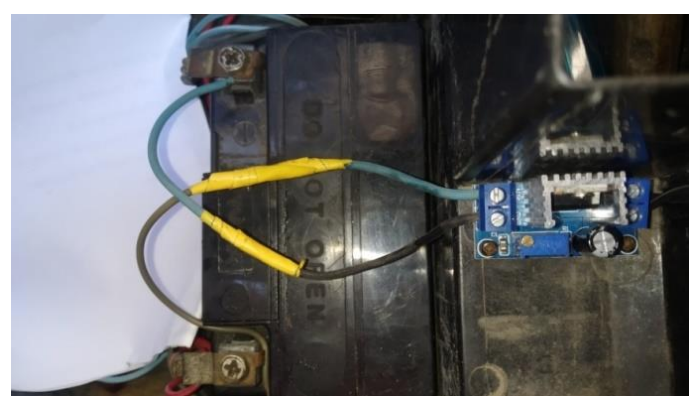

Gambar 10. Pemasangan DC Conventer Regulator 


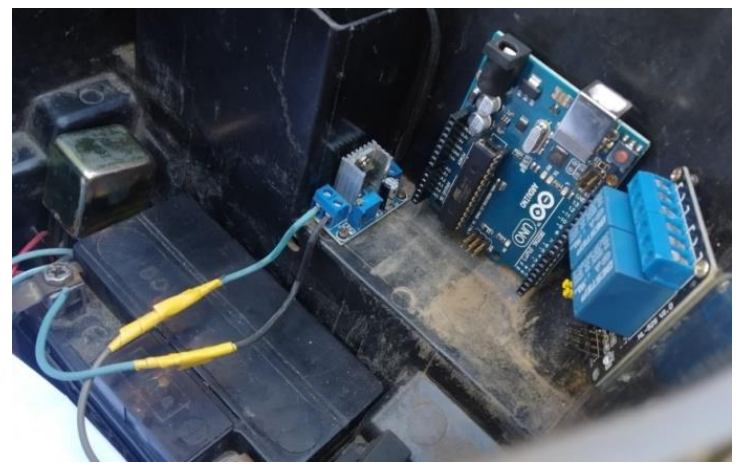

Gambar 11. Pemasangan board arduino uno dan modul relay

\section{HASIL}

Data yang dihasilkan dari penelitian pengembangan yang pertama adalah data yang menerangkan tentang keberhasilan input data bahasa pemrograman arduino pada modul board arduino uno dan alat scanner sidik jari yang terdiri inputan coding pins dan coding sketch.

Tabel 2. Hasil status coding program arduino

\begin{tabular}{cccc}
\hline No & Input Coding & Status & Keterangan \\
\hline 1 & Input Pins & Done Compiling & Berhasil \\
2 & Input Sketching & Done Compiling & Berhasil \\
\hline
\end{tabular}

Data kedua yang dihasilkan merupakan hasil unjuk kerja perakitan kelistrikan yang digunakan untuk starter sidik jari. Uji yang dilakukan adalah uji tegangan kerja sistem sakelar starter sidik jari arduino. Alat dan bahan dalam pengujian ini, yaitu: alat (1) laptop, (2) board arduino uno, (3) modul biometric fingerprint scanner, dan (4) modul relay 2 channel. Untuk bahan, yaitu: (1) kabel jumper dan (2) kabel usb 2.0 type A/B. Berikut tabel hasil pengujian tegangan kerjanya.

Tabel 3. Hasil tegangan kerja sistem sakelar starter sidik jari arduino

\begin{tabular}{lcl}
\hline \multicolumn{1}{c}{ Nama Alat } & $\begin{array}{c}\text { Tegangan } \\
\text { Kerja }\end{array}$ & \multicolumn{1}{c}{ Tegangan Yang Digunakan } \\
\hline Board Arduino UNO & 5 Volt & Port USB pada Laptop \\
Modul biometric fingerprint scanner & 3.3 Volt -5 & Pin 3.3 Volt atau Pin 5 Volt pada Board Arduino \\
Modul relay 2 channel & Volt & Pin 5 Volt pada Board Arduino \\
\hline
\end{tabular}

Hasil data ketiga merupakan hasil uji kondisi modul relay. Modul realay 2 channel akan menyalakan led indicator lamp ketika relay hidup, dan mematikan menyalakan led indicator lamp ketika relay mati. Berikut ini adalah hasil uji coba dalam tabel pada data sketch program arduino dan kondisi relay pada saat aplikasi diaktifkan. Sedangkan hasil kesimpulan pengujian sistem ini adalah bekerja dengan baik.

Tabel 4. Hasil pengujian aplikasi pada program arduino dan kondisi modul relay 2 channel

\begin{tabular}{cccc}
\hline Karakter Data & Fungsi & Relay Ke- & Keterangan Relay \\
\hline a & Kunci Kontak ON & 1 & ON \\
b & Kunci Kontak OFF & 1 & OFF \\
c & Starter & 2 & ON selang waktu 1 detik kemudian OFF \\
\hline
\end{tabular}


Hasil data keempat merupakan hasil implementasi sistem pada sepeda motor Honda Beat dengan pengapian konvensional. Board Arduino hanya menggunakan tegangan kerja 5 volt dc, sedangkan tegangan pada aki sebesar 12 volt dc, maka diperlukan modul dc converter regulator $\operatorname{lm} 317$ yang merubah tegangan input 12 volt de menjadi 5 volt dc dengan memutar potensiometer pada modul dc converter. Berikut adalah data berbentuk tabel tentang tegangan yang diterima board arduino terhadap kondisi modul relay 2 channel.

Tabel 5. Data tegangan yang diterima board arduino terhadap kondisi modul relay 2 channel

\begin{tabular}{ccc}
\hline Tegangan Yang Diterima Board Arduino & \multicolumn{2}{c}{ Kondisi Modul Relay } \\
Kod Indikator & Melay \\
\hline$<3.3$ Volt & Mati & Mati \\
3.3 Volt $-<5$ Volt & Hidup & Mati \\
$>6$ Volt & Hidup & Hidup \\
\hline
\end{tabular}

Data terakhir yang didapat adalah hasil uji pengaplikasian sidik jari terhadap respon sensor sidik jari. Ujicoba ini dilakukan dengan melibatkan empat variable kondisi sidik jari yang telah didaftarkan. Empat kondisi tersebut yaitu kondisi sidikjari user kering, basah, berminyak, berdebu serta satu kondisi pembanding penyalaan menggunakan strarter langsung. Data yang diperoleh merupakan hasil kecepatan waktu penyalaan.

Tabel 6. Data hasil starting terhadap kecepatan waktu penyalaan

\begin{tabular}{|c|c|c|c|c|c|c|c|c|}
\hline \multirow{2}{*}{ No } & \multirow{2}{*}{ Media } & \multicolumn{6}{|c|}{ Pengujian (Detik) } & \multirow{2}{*}{ Rata-Rata } \\
\hline & & 1 & 2 & 3 & 4 & 5 & 6 & \\
\hline 1 & Tangan Kering & 2,01 & 2,12 & 2,62 & 1,45 & 2,82 & 2,83 & 2,31 \\
\hline 2 & Tangan Basah & 3,47 & 3,93 & 3,88 & 3,81 & 3,22 & 3,12 & 3,57 \\
\hline 3 & Tangan Berminyak & 3,63 & 3,33 & 3,81 & 3,55 & 3,81 & 3,18 & 3,55 \\
\hline 4 & Tangan Berdebu & 3,22 & 3,26 & 3,61 & 3,21 & 3,81 & 3,44 & 3,43 \\
\hline 5 & Tombol Starter & 1,36 & 1,22 & 1,21 & 1,22 & 0,98 & 1,28 & 1,21 \\
\hline
\end{tabular}

\section{PEMBAHASAN}

Dalam penelitian pengembangan prototype sistem keamanan model sidik jari berbasis arduino telah rampung dikerjakan. Proses awal meliputi penginputan dan pengunggahan dari aplikasi arduino terhadap board arduino uno dan modul relay 2 channel. Hasil pemrograman menunjukkan bahwa menunjukkan keterangan done compiling sebagaimana pada tabel 2 yang artinya perangkat lunak telah berhasil diaktivasikan pada perangkat keras, hal ini sejalan dengan hasil penelitian yang pernah dilakukan sebelumnya di mana metode pengembangan dilakukan secara dua tahap yaitu tahap pengembangan perangkat lunak dan perangkat keras, lalu keduanya dikonfigurasikan (Prasetya \& Mushlihudin, 2018).

Konfigurasi perangkat lunak ke perangkat keras dalam prototype yang dikembangkan ini memperhatikan faktor rangkaian kelistrikan yang telah didesain dalam wiring diagram. Perangkat keras aplikasi ini berupa board arduino uno, scanner fingerprint, dan modul relay 2 channel yang kesemuanya memerlukan supplay tegangan yang wajar. Pada saat pemrograman sistem sebelum sistem diimplementasikan pada sepeda motor, sistem menggunakan arus dan tegangan dari port USB yang terdapat pada laptop yaitu 1.5 ampere dan sekitar 5 volt. Dalam input pemrograman, diinputkan sebuah syarat yang nantinya menjadi output, yaitu syarat pengaktifan dengan tegangan kerja antara 5 sampai 12 volt dc.

Selanjutnya pada saat implementasi prototype, beban tegangan yang diterima oleh board arduino uno harus disesuaikan dengan kemampuannya dalam menerima tegangan dari aki, penyesuaian ini menggunakan alat tambahan berupa dc converter (Johnson, 2017). Penyesuaian ini dilakukan untuk mengoptimalkan kerja modul relay 2 channel yang aktif dengan optimal dengan tegangan lebih dari 5 volt de dan akan mati ketika menerima tegangan di bawah dari 3.3 volt de sebagaimana hasil data tabel 5.

Proyotype yang telah dirangkai pada sepeda motor telah siap diaplikasikan sistem keamanannya dari potensi kemalingan. User atau pengguna sepeda motor yang dilengkapi sistem keamanan jenis ini harus didaftaran lebih dahulu. Pada proses pendaftaran menggunakan beberapa alat dan bahan, antara lain sidik jari user, modul biometric fingerprint, SFG Demo on Windows, mikrokontroler arduino uno. Dalam proses tersebut dilakukan pendaftaran dan pencocokan sidik jari yang nantinya hasil datanya akan tersimpan dalam sistem yang telah dikembangkan. Akurasi verifikasi pencocokan ini sebesar $100 \%$ bekerja yang senada juga dari hasil pengembangan tingkat keamanan melalui sidik jari dalam penelitian sebelumnya (Tatik Juwariyah, 2017). 


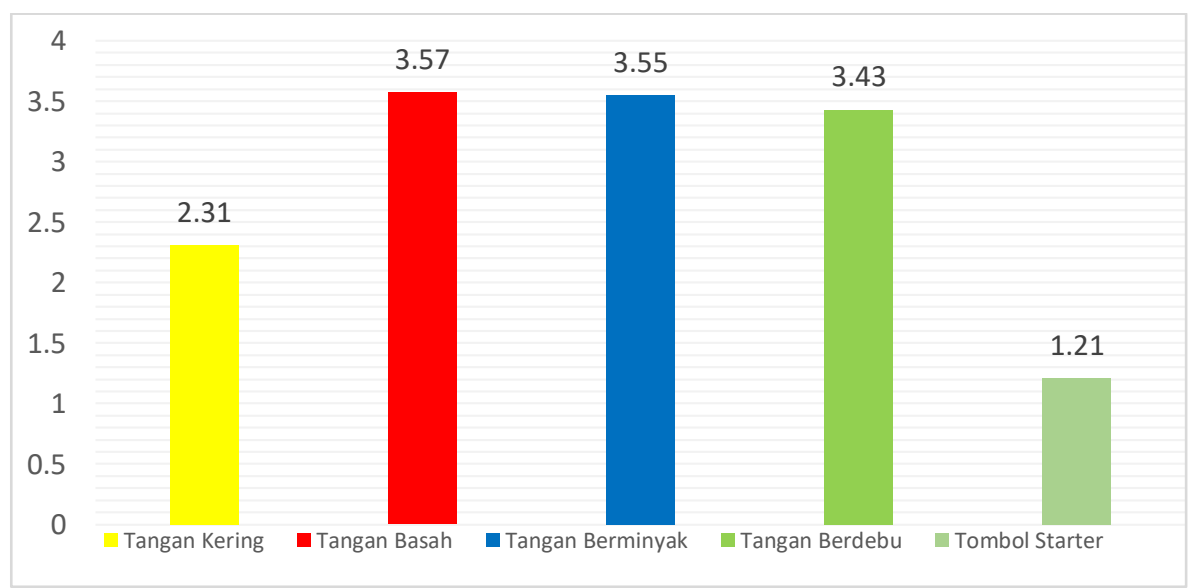

Gambar 12. Grafik hasil uji coba penyalaan starter menggunakan aplikasi sidik jari

Untuk mengetahui tingkat kelemahan penyalaan starter, maka diujikan dengan berbagai kondisi penghambat pembacaan sidik jari dengan hasil seperti pada grafik di atas. Kondisi yang menghambat pembacaan antara lain kondisi sidik jari kotor dan berdebu, basah, serta berminyak. Hal itu mempengaruhi waktu penyalaan. Jadi kondisi paling optimal verifikasi sidikjari untuk starter sepeda motor adalah kondisi sidik jari ketika kering dan bersih dengan kecepatan waktu starting 2,31 detik, dan waktu terlama rata-rata starting adalah kondisi sidik jari basah dengan waktu penyalaan 3,57 detik. Sedangkan keunggulan sistem keamanan ini adalah ketika sistem bekerja tidak membaca sidik jari yang sebelumnya belum pernah terdaftar, maka alarm akan diaktifkan oleh aplikasi (Ajith Kumar.S, Amara Adhithiya Cholzaa.C.K, Arulraj.R, Charan Kumar.P, 2018). Hasil pengaktifan alarm ini akan menimbulkan perhatian lingkungan sekitar akibat bunyi alarm, sehingga potensi resiko kejahatan pencurian dapat dicegah dengan alat ini, demikianlah fungsi kerja perangkat anti maling berbasis digital yang menyuguhkan beberapa tingkat keamanan yang cocok untuk diaplikasikan pada sepeda motor (Noman et al., 2019).

\section{PENUTUP}

Prototype ini dikembangkan dengan dua langkah, yang pertama pengembangan perangkat lunak dan kedua dilanjutkan dengan pengembangan perangkat kerasnya. Kedua tahapan itu lalu di-assembly atau dikonfigurasikan hingga sistem pada prototype siap dioperasikan. Dalam pengujian yang telah dilakukan, rata-rata penyalaan tercepat ketika kondisi sidik jari user kering dan bersih dengan waktu rata-rata 2,31 detik, dan kondisi pembacaan terlama ketika kondisi basah dengan rata-rata waktu penyalaan 3,57 detik. Dalam uji tersebut dikategorikan menjadi empat kondisi sidik jari yaitu kering, basah, berminyak, berdebu, dan dibandingkan dengan waktu penyalaan rata-rata menggunakan kunci kontak dengan frekuensi uji coba masingmasing enam kali. Apabila sidik jari user belum pernah sama sekali didaftarkan, maka akan memuat gagal verifikasi sehingga sistem akan membunyikan alarm sebagai tanda sistem keamanan mengalami gangguan keamanan berupa pembobolan akses oleh user tak dikenal..

\section{DAFTAR RUJUKAN}

Ajith Kumar.S, Amara Adhithiya Cholzaa.C.K, Arulraj.R, Charan Kumar.P, S. (2018). Biometric Based Ignition System Using Arduino. IJIRSET, 7(1), 147-150.

Bachri, A. (2018). Rancang Bangun Sistem Keamanan Sepeda Motor Dengan Fingerprint Berbasis Telephone. JE-Unisla, 3(2), 19.

Brijet, Z., Kumar, B. S., \& Bharathi, N. (2017). Vehicle Anti-Theft System Using Fingerprint Recognition Technique. Open Academic Journal of Advanced Science and Technology, 1(1), 36-41. https://doi.org/10.33094/5.2017.11.36.41

Hendrawan, M. B., \& Pratomo, D. . (2020). Rancang Bangun Sakelar Bluetooth Arduino Via Smartphone Pada Sepeda Motor Honda Revo. STEAM Engineering, 2(1), 38-43. 
JURNAL TEKNIK MESIN DAN PEMBELAJARAN, Volume 3, Nomor 2, Desember 2020, Halaman: 99- 108

Johnson, J. P. (2017). DC-DC converters. In Handbook of Automotive Power Electronics and Motor Drives. https://doi.org/10.1201/9781420028157

Kementerian Perindustrian Republik Indonesia. (2018). Sektor-Sektor Manufaktur Andalan Tahun 2018. Kementerian Perindustrian Republik Indonesia.

Khan, P. R., Ahmed, S., Khan, F., Ko, P., \& Akhtar, B. (2017). Biometric Scanning Based on Vehicle Ignition System. IJESC, 7(3), 5731-5734.

Noman, A. T., Hossain, S., Islam, S., Islam, M. E., Ahmed, N., \& Mahmud Chowdhury, M. A. (2019). Design and Implementation of Microcontroller Based Anti-Theft Vehicle Security System Using GPS, GSM and RFID. 4th International Conference on Electrical Engineering and Information and Communication Technology, ICEEiCT 2018. https://doi.org/10.1109/CEEICT.2018.8628051

Prasetya, D. I., \& Mushlihudin, M. (2018). Sistem Keamanan Sepeda Motor Menggunakan Kata Sandi Berbasis Arduino Nano. Jurnal Ilmiah Teknik Elektro Komputer Dan Informatika, 4(1), 11. https://doi.org/10.26555/jiteki.v4i1.8985

Tatik Juwariyah, A. C. D. (2017). Rancang Bangun Sistem Pengaman Sepeda Motor Dengan Sensor Sidik Jari. Ejournal Universitas Pembangunan Nasional “Veteran” Jakarta, 13, 102-107. 